\title{
Studies on Ornitbobilharzia turkestanicum (Skrjabin, 1913), Price, 1929 in Iran ${ }^{(1)}$
}

\author{
By F. ARFAA (2), H. SABAghiaN (3) and H. ALE-DAWOOD (4)
}

\section{INTRODUCTION.}

Ornithobilharzia turkestanicum, first described by Skrjabin in 1913, was reported in Turkestan, Mongolia, France, Iraq and Pakistan perior to this study (1, 2, 3, 4, 5).

Mac Hattie (1963) studied the life history of these species and observed its presence in cattle, sheep, goats, horses, mules and camels in Iraq (4).

This infection was discovered in Iran in 1962 during investigations on the snailborn diseases of animals, carried out by the Bilharziasis Research Station in the Bilharziasis Pilot Project Area in Dezful, northern Khuzistan.

\section{STUDIES UNDERTAKEN.}

1. - Field studies: The guts and mesenteries of ruminants slaughtered in villages situated in the selected area for biiharziasis surveys in the vicinity of Dezful were randomly selected and brought to the Dezful Station Laboratory to be examined.

Flukes collected from the viscera were identified as $O$. turkestanicum and their identification confirmed by Dr. J. A. Dinnik, East African Veterinary Research Organization, Kenya. Examination of the viscera of cattle, goats, sheep, camels and wild boar of this area revealed the presence of $O$. turkestanicum in these animals.

Table 1 shows the number of animals examined and the rate of infection among them.

Because of the presence of the intermediate host of this trematode in other parts of Iran (Map 1) a limited investigation was carried out in the Teheran slaughter house where $O$. turkestanicum flukes were found in the mesenteric veins of one cow and one sheep, which were apparently form the northern part of Iran.

(1) These studies were supported in part by the Institute of Parasitology and Malariology, School of Medicine, Teheran University, and in part by the WHO assisted Bilharziasis Control Pilot Project of the Ministry of Hearth and Plan Organization Development Project $\mathrm{N}^{\circ} 777$.

(2) Assistant Professor of Parasitology, School of Medicine, Teheran University, and Chief of the Bilharziasis Research Station of the Institute of Parasitology and Malariology, P.O.B. 6, Dezful, Khuzestan, Iran. Iran.

(3) In charge of Veterinary Section, Dezful Research Station P.O.B. 6, Dezful, Khuzistan,

(4) Research Assistant. In charge of the Dezful Airforce Sanitary Corps. 


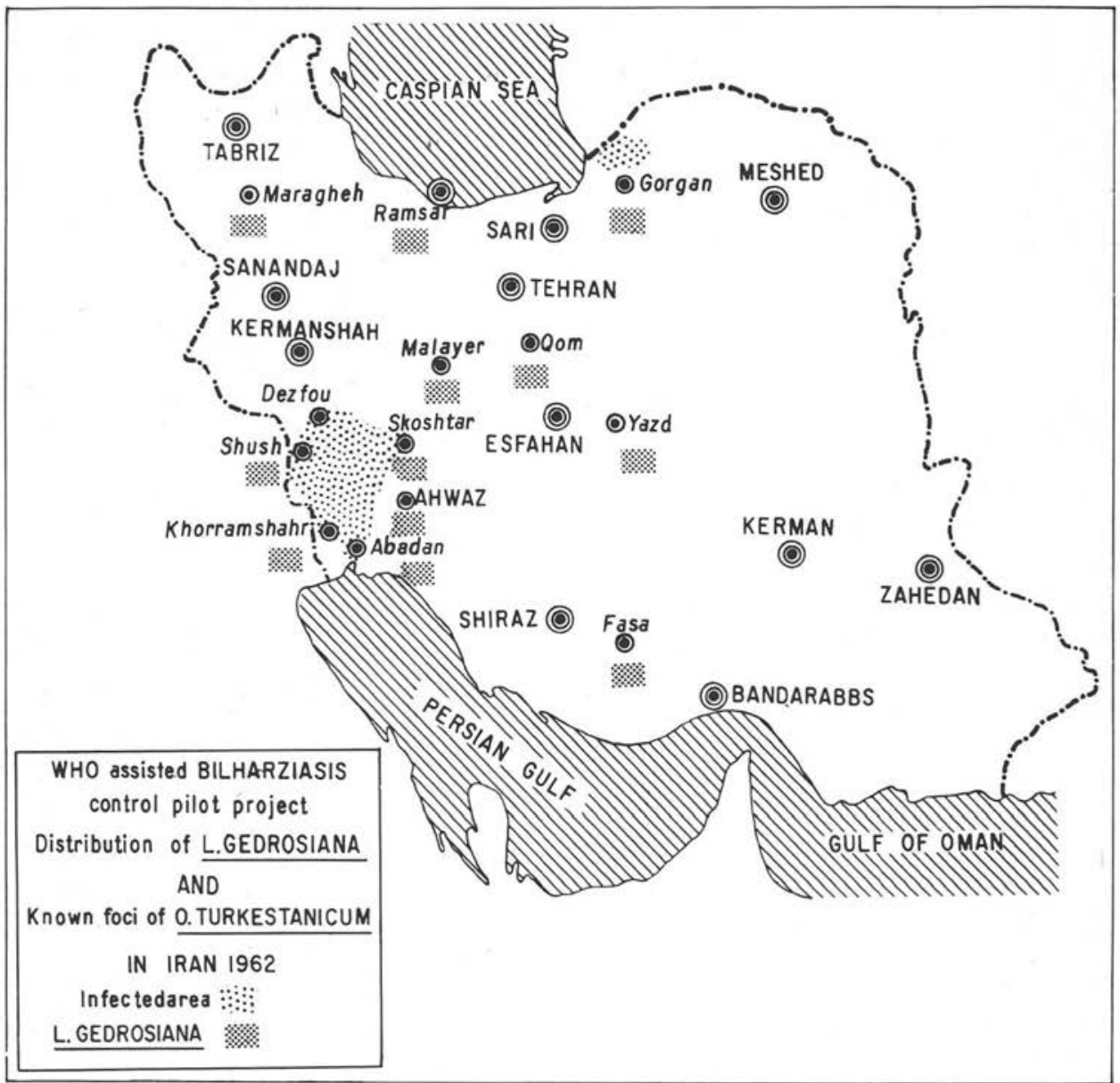

2. - Laboratory studies : Studies were undertaken to determine the molluscan intermediate host and to trace the life cycle of this trematode in Iran.

Because of the high density of Lymnaea gedrosiana and a large number of $O$. turkestanicum in the project area, a relationship between these two was suspected. Therefore, a large number of L. gedrosiana collected from bodies of water near villages with infected animals was brought to the laboratory and examined either by the crushing method or by placing them under the light so they would shed cercariae.

Among 2880 Lymnaea examined, 7 were found infected with furcocercous cercariae. These cercariae were used to infect five Tatera indica. 80-82 days after exposure mature $O$. turkestanicum were found in the liver and mesentric veins of 2 of these rodents. 
Table I

Animals Infected with $O$. turkestanicum in Villages Near Dezful in 1962

\begin{tabular}{|c|c|c|c|}
\hline $\begin{array}{c}\text { Animal } \\
\text { Examined }\end{array}$ & $\begin{array}{c}\text { No. } \\
\text { Examined }\end{array}$ & $\begin{array}{c}\text { No. } \\
\text { Infected }\end{array}$ & $\begin{array}{c}\% \\
\text { Positive }\end{array}$ \\
\hline Cow $\ldots \ldots \ldots \ldots$ & 185 & 128 & 69 \\
\hline Sheep $\ldots \ldots \ldots \ldots$ & 53 & 15 & 28.3 \\
\hline Buffalo $\ldots \ldots \ldots \ldots$ & 31 & 11 & 35.4 \\
\hline Goat $\ldots \ldots \ldots \ldots$. & 4 & 4 & 100 \\
\hline Camel...$\ldots \ldots \ldots$ & 9 & 4 & 44.4 \\
\hline Wild boar $(+) \ldots$ & 1 & 1 & $\frac{(+1)}{1}$ \\
\hline Total $\ldots \ldots \ldots \ldots$ & 283 & 163 & 57.5 \\
\hline
\end{tabular}

(*) Accidentally killed.

Again 90 laboratory-bred L. gedrosiana were experimentally infected with miracidia hatched from eggs of $O$. turkestanicum, collected by scraping the intestinal mucosa of one infected cow and buffalo (both infected only with O. turkestanicum). These Lymnaea started shedding cercariae 21 days after exposure to infection; 52 of them were infected. One group of 10 Tatera indica was experimentally infected with a known number of cercariae; mature flukes were recovered from all of them. The result of this experiment is summarized in Table 2.

In order to find other susceptible animals, 10 albino rats, 2 rabbits and 4 guinea pigs were also experimentally infected with 40-50 cercariae from experimentally infected Lymnaea. Eight albino rats were autopsied 2-3 months after exposure and only 2 male Ornithobilharzia flukes were found in the liver of one rat.

In one rabbit infected with 900 cercariae, autopsied 102 days after exposure, 376 fluks (299 males and 77 females) were found in the liver and mesentric veins. The other rabbit and one of the guinea pigs were autopsied before the prepatent period and found negative. Another guinea pig infected with 1000 cercariae revealed only 9 flukes 39 days after exposure. The last 2 guinea pigs are still under observation.

\section{DISCUSSION AND CONCLUSION :}

O. turkestanicum is prevalent among the ruminants of the villages of northern Khuzistan. It is, however difficult to restrict the infection to separate villages since ruminants of several villages use water from snail breeding places situated in different areas; thus the distribution of infection as shown in map 1 is based on the villages where host animals are kept. 
Table II

The Result of Study on Susceptibility of Tatera indica to O. turkestanicum DEZFUL - 1962

\begin{tabular}{|c|c|c|c|c|c|}
\hline \multirow{2}{*}{$\begin{array}{l}\text { Serial } \\
\text { No. of } \\
\text { Animal }\end{array}$} & \multirow{2}{*}{$\begin{array}{c}\text { Days Elapsed } \\
\text { Between Exposure } \\
\text { \& Autopsy }\end{array}$} & \multirow{2}{*}{ No. of Cercariae } & \multicolumn{3}{|c|}{$\begin{array}{l}\text { No. of flukes } \\
\text { Recovered }\end{array}$} \\
\hline & & & male & female & total \\
\hline 1 & 53 & 1.000 & 147 & 193 & 340 \\
\hline 2 & 115 & 1.000 & 84 & 121 & 205 \\
\hline 3 & 64 & 300 & 31 & 7 & 38 \\
\hline 4 & 65 & 300 & 42 & 24 & 66 \\
\hline 5 & 123 & 500 & 10 & 10 & 20 \\
\hline 6 & 187 & 300 & 38 & 40 & 78 \\
\hline 7 & 196 & 500 & 17 & 31 & 48 \\
\hline 8 & 178 & 1.000 & 106 & 101 & 207 \\
\hline 9 & 176 & 500 & 29 & 12 & 41 \\
\hline 10 & 173 & 500 & 46 & 28 & 74 \\
\hline
\end{tabular}

Since $L$. gedrosiana, presently known intermediate host of the parasite, has been found in other parts of Iran, the infection probably occurs in other parts of this country. The low infection rate of snails studied during winter time is probably the effect of the unfavourable season. The biology of this trematode as well as the overall distribution of the disease and other possible intermediate hosts should be determined by further investigations.

Among laboratory animals used, Tatera indica, which is common in this area, has proved to be most susceptible to infection.

Rabbits, although they produce a large number of adult flukes, are poor hosts since none of the eggs obtained from their viscera hatched out during this limited experiment. Similary, guinea pigs and albino rats seem to be poor hosts. Further studies are underway which will enable us to give a clear cut view about the degree of susceptibility of common laboratory animals to this trematode.

In connection with the presence of this infection in man the examination of about 9000 urine and 1000 feces samples from the inhabitants of villages with breeding places highly infected with $L$. gedrosiana, has not revealed a single case of infection.

\section{Summary}

The presence of $O$. turkestanicum in Khuzistan (and from a single observation in the north part of Iran) and its prevalence among cattle, sheep, goats, camels and wild boar of the bilharziasis infected area was determined. The role played by Lymnaea gedrosiana as an intermediate host of infection was confirmed. 


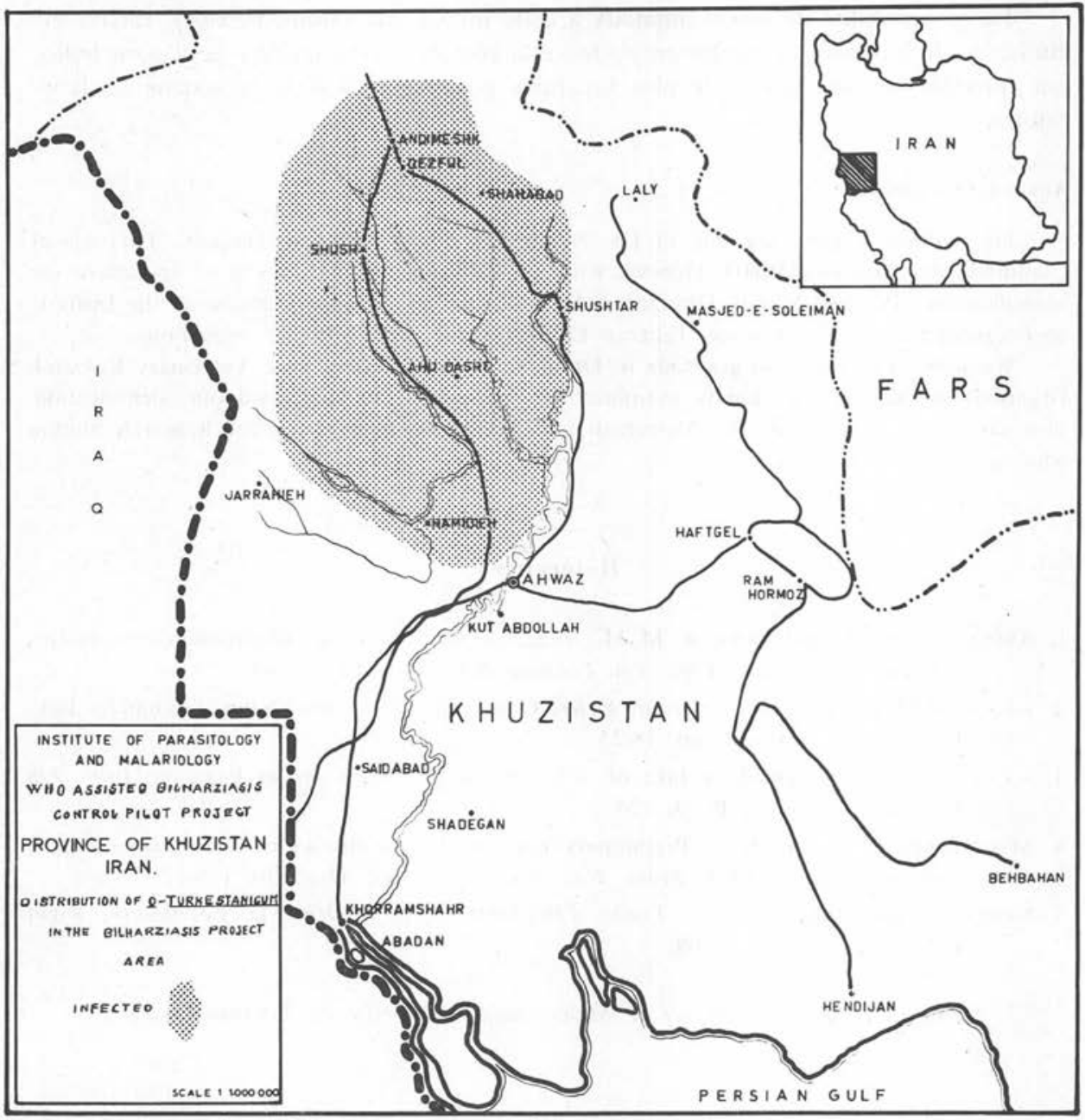

Susceptibility of different animals (rabbits, guinea pigs, rats) was studied, and Tatera indica was found to be the best prospect for laboratory life cycle maintenance.

\section{Résumé}

La présence d'Ornithobilharzia turkestanicum chez les Ruminants du Khuzistan septentrional est signalée. La fréquence dominante de ce parasite s'observe parmi les Bovins, Ovins (chèvres, moutons), chameaux et sanglier. Le rôle joué par Limnaea gedrosiena comme hôte intermédiaire de ce Trématode est établi. 
La susceptibilité de divers animaux à cette infestation (lapins, cobayes, rats) a été étudiée ; elle a permis de mettre en évidence la réceptivité particulière de Tatera indica qui apparaît comme l'animal le plus favorable pour l'entretien de la souche au laboratoire.

\section{ACKNOWLedGements ;}

The authors' thanks are due to Dr. N. Ansari, Chief, Parasitic Diseases, Division of Communicable Diseases, WHO, Geneva, who has helped us with shipment of specimens for identification; Dr. Ch. Mofidi, Director and Dr. H. Bijan, Assistant Director of the Institute of Parasitology and Malariology, Teheran University for their valuable suggestions.

We wish to express also gratitude to Dr. J. A. Dinnik, East African Veterinary Research Organization, Kenya, who kindly examined the specimens and confirmed our identification. Our thanks go also to Mr. K. Movafagh and other members of Desful Research Station who helped us in this study.

\section{Références}

1. Abdulssalam, M. and Sarwar, M. M., 1952. - Occurrence of Ornithobilharzia turkestanicum in Pakistan., Proc. 4th. Pakistan Sci. Conf., Pt. 3. 143.

2. - - 1953. - In : XV Internat. Veter. Congr. Proceed., Stockholm, Gernandts Boktryckeri, Pt. 1, vol. 1, pp. 18-23.

3. - - 1953. - Intermediate host of Schistosoma turkestanicum in Pakistan. Proc. 6th Pakistan s'ci. Conf., Pt. 3, 225.

4. Mac Hattie, C. A., 1936. - Preliminary note on the life history of Schistosoma turkestanicum Skrjabin, 1913. Trans. Roy. Soc. Trop. Med. Hyg., 30, 115-128.

5. Neveu-Lemaire, M., 1936 - Traité d'Helminthologie Médicale et Vétérinaire, Vigot Frères, édit., Paris, p. 309.

Institut de Parasitologie et de Malariologie. Université de Téhéran (Iran) 